\title{
SIGNOS DO CONSUMO: O JOGO EXPRESSIVO DAS MARCAS E DA PUBLICIDADE
}

\author{
Eneus Trindade ${ }^{1}$ \\ Clotilde Perez ${ }^{2}$
}

A primeira edição de 2012 da Revista Signos do Consumo oferece aos seus leitores reflexões abrangentes e densas sobre as interfaces da comunicação contemporânea, a partir de duas áreas grandes áreas: o consumo, por meio da publicidade e as marcas. Centralidade da vida social contemporânea, o consumo se afirma como locus identitário e de expressão da cidadania pós-moderna, com todas as críticas e benesses inerentes a essa condição e que são problematizadas em vários dos textos desta edição. Já as marcas, crescem como manifestação simbólica e caminho para segurança psíquica, no mesmo sentido em que “escapam das mãos” de gestores acostumados com o total controle do passado e que agora, no mínimo, compartilham com os consumidores não apenas as escolhas, como também a autoria de suas expressões.

Assim, o primeiro artigo de Allan Kozlakowski, da Pontifícia Universidade Católica de São Paulo, intitulado "Contratos de comunicação e análise do discurso: bases teóricas aplicadas ao enunciado persuasivo de moda masculina” apresenta competente reflexão sobre a comunicação persuasiva no discurso do empreendedor de sucesso presente nas revistas Você SA e Exame, bem como em campanhas publicitárias de moda masculina. Por meio da metodologia da análise do discurso, promove um aprofundamento no entendimento do intrincado sistema de construção do discurso persuasivo, tanto em conteúdos jornalísticos, quanto na publicidade.

Os dois artigos que seguem têm em comum a marca Hermés, como objeto de estudo. O primeiro texto "A cena fabulística de Hermés: uma perspectiva semiótica sobre

\footnotetext{
${ }^{1}$ Professor Doutor do Departamento de Relações Públicas, Propaganda e Turismo da ECA/USP. Possui pósdoutorado em Antropologia Visual pela Universidade Aberta de Portugal. Doutor e Mestre em Comunicação pela ECA/USP. Docente do PPGCOM/ECA/USP na área de teoria e pesquisa em comunicação e Coordenador do Grupo Interdisciplinar de Estudos da Linguagem Publicitária CNPq/ECA/USP.

${ }^{2}$ Professora Livre Docente em Ciências da Comunicação do Departamento de Relações Públicas, Propaganda e Turismo da ECA/USP. Possui pós-doutorado em Comunicação pela Universidade de Murcia-Espanha. Doutora em Comunicação e Semiótica pela PUC-SP, Mestre em Administração pela PUC-SP. Docente do PPGCOM/ECA/USP na área de interfaces sociais da comunicação. Coordenadora dos Grupos de Estudos Semióticos em Comunicação, Cultura e Consumo CNPq/ECA/USP.
} 
Signos do consumo: o jogo expressivo das marcas e da publicidade

de Eneus Trindade e Clotilde Perez

as narrativas da marca”, de autoria de Bruno Pompeu, doutorando do PPGCOM ECA USP e Clotilde Perez, orientadora no mesmo programa, descrevem e analisam os engendrados e imaginativos caminhos utilizados pelos estrategistas da marca na busca de edificar mensagens que permitam a construção de vínculos afetivos com seus consumidores-alvo. Para tanto, apresetam detalhamente análise semiótica da campanha "La vie comme un conte" integrando as reflexões acerca da produção de sentido a partir de Barthes, Greimás, Floch e Semprini. Já o segundo texto “Hermés: expressões da marca e rituais de consumo”, com autoria compartilhada entre Flavia Gonsales, Diogo Kawano e Janiene Santos, FAU e ECA - USP oferecem um percurso aprofundado das diferentes expressões da marca Hermés por meio da semiótica peirceana, bem como o detalhamento dos rituais de consumo (McCracken, 2003) implicados na campanha "Le temps avec soi”.

De pesquisadores portugueses vêm a contribuição por meio do texto "As crianças $e$ as marcas: que relação possível? Um olhar sobre as mascotes”, de autoria de Ana CorteReal e Paulo Lencastre, ambos da Universidade Católica Portuguesa. O texto integra reflexão teórica com pesquisa de campo, por meio da realização de grupos focais com crianças. Apresenta importante contribuição para o estudo da relação entre as marcas e o público infantil, com foco na mediação das mascotes. A pesquisa traz destacados resultados que podem ser facilmente acionáveis tanto para quem se dedica ao estudo do tema, quanto para aqueles que precisam planejar e executar campanhas publicitárias nesse âmbito.

Também integrando as reflexões sobre o universo sígnico das marcas, temos o texto "A importância do emocional na política da marcária”, de Jean-Charles Zozzoli, professor da Universidade Federal de Alagoas, diretor científico da ABP2 - Associação Brasileira dos Pesquisadores em Publicidade. O artigo apresenta o debate teórico e crítico do tema, com o intuito de entender a marca como fornecedora de percepções e experimentos não só sociorrelacionais, mas também a disposições afetivas fundamentais que provocam reações emocionais de afinidade, afeição, adesão, paixão, indiferença, distanciamento, ira, repulsa etc., a marca contemporânea é provedora de todas essas experiências, gerando elementos temporários de monopólio simbólico e econômico apoiando-se em percepções que substituem características racionais por experiências emocionais e sensoriais, algo vivenciado tanto no plano propriamente físico quanto na imaginação. Como sempre, o autor 
Signos do consumo: o jogo expressivo das marcas e da publicidade

de Eneus Trindade e Clotilde Perez

nos oferece um aprofundamento teórico rigoroso com a leveza da criatividade franconordestina.

A relevância mercadológica da população de baixa renda no Brasil é notória, principalmente após os avanços de renda e de melhoria geral da qualidade de vida dessa faixa da população. Evidentemente, tais fenômenos trazem fortes impactos nas relações de comunicação e consumo e é sobre esses temas que o artigo de "O consumo, o gosto, a ponte e a cerca: um estudo exploratório sobre gosto e referências estéticas em propagandas dirigidas à baixa renda", de Jôse Fogaça, doutoranda do PPGCom - ECA USP, trata. O texto discorre a acerca do processo histórico de fortalecimento da população debaixa renda no Brasil, bem como busca identificar as diferenças nas semânticas expressivas na comunicação destinada a esse público. Para tanto, utiliza-se da propaganda assumidamente focada na baixa renda, como manifestação privilegiada dessas diferenças.

Ainda sobre o consumo, mas na perspectiva que compara a dimensão presencial com o consumo digital é que trata o artigo "As formas de vida do consumo digital e tradicional". Os autores Sergio Bairon, da ECA USP e Lawrence Koo da Pontifícia Universidade Católica de São Paulo, constroem o percurso que manifesta as congruências e diferenças que o consumo evidencia em cada um dos ambientes em análise, permitindo assim, o entendimento das particularidades de cada um, além de fornecerem subsídios para desdobramentos investigativos no sentido de identificar formas comunicacionais mais adequadas.

Como vimos o primeiro número de 2012 da Revista Signos do Consumo cumpre com o compromisso de apresentar destacadas reflexões na convergência entre a comunicação, a cultura e o consumo, sempre com vistas a ampliar o diálogo interdisciplinar e oferecer espaço e abrigo para o avanço da pesquisa e de publicações qualificadas na área.

Boa leitura!

Os Editores 